\title{
Systemic Reformulation of Labour Arrangements Between Demand and Pressure Concerning Income towards Welfare in Indonesia*
}

\author{
Abdullah Sulaiman ${ }^{1}$ \\ Universitas Islam Negeri Syarif Hidayatullah Jakarta \\ dol $10.15408 /$ jch.v8i2.15622
}

\begin{abstract}
s
The abstract of this article authors several points, among others: Firstly, Purpose of Article; to analyze labor regulation concerning income provision towards welfare for employers in Indonesia. Secondly, Scope of Work; that the legal implementation focuses on Indonesian labor law arrangements, and then concerning pressures relevant to income as an international standard for laborers, and demand for wage acceptance as a facility for labor welfare, and also labor law dispute settlement in the Indonesian welfare system. Thirdly, Legal Methodology; refers to qualitative research with secondary materials from normative and empirical sources, also by conducting legal comparison from other countries outside of Indonesia. Fourthly, Result in Summary; on the systemic implementation of Indonesian labor regulation as stipulated in a written constitution, that "Each citizen shall reserve the rights for adequate employment and income based on sustainable standards (Article 27 paragraph (2), 1945 Indonesian Constitution). The income pressure for International labor standards via ILO has created a standard system to protect the rights of laborers binding themselves in an agreement, based on ILO Convention No.89 the Year 1949 which instigated the birth of Law Number 18 the Year 1956 concerning Ratification of ILO Convention No. 80 the Year 1957. Demands for income to be accepted as labor welfare has yet to reiterate the importance of wage component in applicable labor law (Law Number 13 the Year 2003 concerning Employment) since it allows Governor in each province to regulate the measurement of labor's wage on annual basis. Similarly with labor trial pattern which only allows the Industrial Relations Court and not solely referring to labor arbitration institution as expected from ILO and WTO as international organizations. Fifthly, Conclusion; that systemic reformulation of labor regulation to achieve welfare in Indonesia still requires the participation or internal demand from laborers and pressure from international labor institutions.
\end{abstract}

Keywords: Income Regulation, Indonesian Labour Welfare.

\footnotetext{
* Received: January 19, 2020, revised: March 21, 2020, accepted: July 21, 2020, Published: August 4, 2020.

${ }^{1}$ Abdullah Sulaiman is a Professor at the Faculty of Sharia and Law. Universitas Islam Negeri Syarif Hidayatullah Jakarta. This writing was assisted by Andi Walli and the team. Corresponding Author: abdullah.sulaiman@uinjkt.ac.id.
} 


\title{
Reformulasi Sistemik Pengaturan Ketenagakerjaan Antara Permintaan dan Tekanan Terkait Pendapatan untuk Kesejahteraan di Indonesia
}

\begin{abstract}
Abstrak
Tujuan Penulisan artikel ini untuk menganalisis pengaturan perburuhan dalam pemberian penghasilan menuju kesejahteraan oleh pengusaha di Indonesia. Sedang ruang Lingkupnya bahwa pelaksanaan hukum pengaturan hukum perburuhan Indonesia, kemudian terhadap tekanan mengenai penghasilan dari standar buruh Internasional, dan tuntutan penerimaan penghasilan sebagai fasilitas kesejahteraan buruh, juga sistem penyelesaian hukum perburuhan dalam sistem kesejahteraan di Indonesia. Metode Penelitian digunakan adalah menggunakan cara penelitian kualitatif dengan bahan sekunder dari bahan hukum normatif dan empiris, juga melakukan perbandingan hukum dari luar Indonesia. Hasilnya bahwa terhadap penerapan sistemik pengaturan perburuhan Indonesia yang telah dijabarkan dalam konstitusi tertulis menekankan bahwa" tiap-tiap warga negara berhak atas pekerjaan dan penghidupan yang layak bagi kemanusiaan" (Pasal 27 ayat (2) UUD 1945). Tekanan penghasilan dari standar buruh Internasional melalui ILO telah menciptakan suatu sistem standar melindungi hak buruh mengikatkan diri di dalam perjanjian yang konvensi ILO No.89 Tahun 1949 mengenai lahir UU No.18 Tahun 1956 tentang Persetujuan Konvensi ILO No.80 Tahun 1957. Tuntutan penerimaan penghasilan sebagai kesejahteraan buruh belum memberikan penegasan komponen upah dalam perundang buruh berlaku (UU No.13 Tahun 2003 tentang Ketenagakerjaan) karena memberikan pada setiap pemerintahan Gubernur setiap provinsi untuk mengatur besar-kecil pengupahan buruh untuk setiap tahunnya.

Kata Kunci: Pengaturan Penghasilan, Kesejahteraan Buruh Indonesia.
\end{abstract}

\section{Системное изменение условий труда между спросом и давлением в отношении доходов для обеспечения благосостояния в Индонезии \\ Аннотация}

Цель исследования: проанализировать трудовые условия при предоставлении дохода для обеспечения благосостояния предпринимателями в Индонезии. Предмет исследования: выполнение и условие трудового законодательства Индонезии, затем давление на доход со стороны международных трудовых стандартов и требования 0 принятии дохода в качестве объекта социальной сферы для рабочих, и также системы урегулирования трудового законодательства в системе социального обеспечения в Индонезии. Используемые методы исследования: качественный метод исследования с использованием вторичных материалов из нормативных и эмпирических правовых материалов, а также в проведении юридических сравнений за пределами Индонезии. Результаты исследования: применение индонезийских трудовых норм, описанных в писаной конституции, подчеркивают, что « каждый гражданин имеет право на труд и достойную жизнь для человечества» (пункт (2) статьи 27 Конституции 1945 года). Давление на доходы со стороны международных трудовых стандартов через МОТ привело к созданию стандартной системы защиты прав трудящихся в соответствии с Конвенцией МОТ № 89 от 1949 года о принятии Закона № 18 от 1956 года об Утверждении Конвенции МОТ № 80 от 1957 года. Что касается благосостояния рабочих, он не подтвердил компонент заработной платы в применимом трудовом законодательстве (Закон № 13 от 2003 года о рабочей силе), поскольку он даёт правительству каждого губернатора каждой провинции право регулировать сумму заработной платы на каждый год. Точно так же модель трудового правосудия допускает только PPHI (Разрешение Производственных Споров), а не единственное учреждение арбитражного урегулирования трудовых конфрликтов, как ожидается от мировых учреждений МОТ и ВТО.

Ключевые слова: Управление доходами, Благосостояние индонезийских рабочих. 


\section{A. INTRODUCTION}

Creation of Labour Law regulation or "Manpower" or "Ketenagakerjaan". The author refers to the term "labor" which translates into manpower/workforce/human resource/staff/ employee due to the simile with "labor". From the reformation era in 1998 until now, Indonesia's entry as a member of the United Nations (UN) is inseparable from her admission as a member of ILO in 1950. Based on the Versailles Treaty, ILO was established in 1919. ILO has advocated whether during the Dutch Indies or Indonesian Government era to adhere with ILO convention terms concerning labor standards (Abdullah Sulaiman, 2006: 20). In 1994, Indonesia has committed to the international community to adjust its national law in economic and trade fields via regulatory management and WTO and ILO agreements concerning Labour Law which paved the way to the convention mandating Indonesia to ratify international customary law into constitutional bodies and legal regulations.

Labor standards have attained the attention of the World Trade Organization (WTO), International Labour Organization (ILO) which was established in 1950 simultaneously with the presence of the League of Nations (LBB). After LBB was dissolved in 1946, the institution was replaced by the United Nations (UN). Shortly after, ILO became the first special body to join the UN, which enjoyed an increase of membership from 45 nations to 153 nations in 1992. Indonesia became a member of the ILO and had at one time removed itself from the UN membership. However, this does not automatically translate into resignation from ILO since the membership of ILO and UN are separate. A state may become a member of ILO despite not being a member of the UN and vice versa (Sulaiman, 2005). However, WTO does not have a work plan agenda to set up labor standards, due to a myriad of state regulations as a strategy to handle its internal trade and other impacts such as globalization which has delivered Indonesia into the intersection between demand and pressure. Ultimately, this condition applies to the Indonesian labor situation.

This national labor organization has been affected by the world trade system with export orientation and import-oriented factory industries which prioritizes respective mutual approval of both parties' labor standards (Wet, 1995: 462). International labor organizations have monitored the unilateral treatment against laborers in Indonesia so that ILO objects to the unfair system, especially with its incumbent servitude pattern (Shamad, 1992: 114). It was found out that the Indonesian government has yet to fully implement it due to unconducive social, political, and economic situations, unfit for implementation. To date, ILO with the Indonesian government and business community remains 
indecisive to consider labor welfare issues. Despite focusing on labor laws, this issue presents an implication to the minimum labor standards. As of now, the current standard for laborers is 40 working hours ins a week, with holidays on Saturday and Sunday (Covington and Decker, 1995: 286). The company should also provide overtime pay on normal working days, weekends, resting days for 6 days of work, premium, lunch money excluding bonus, holidays, health insurance. Aside from that, the company must also provide temporary housing and health facilities for laborers (Fraser, 1991: 454), all due to the public axiom whereas the parties are currently negotiating to stimulate labor welfare due to non-standard labor contracts.

Fundamental understanding concerning overall costs for negotiation purposes has somewhat made it economically irrational for all parties to include long effects terms. This includes information imbalance which directs the parties to avoid income programs against a standardized process that will deduct labor welfare components. As such, to obtain a sustainable income pattern, the overall labor income components were drafted by the government into a law that regulates labor wage standards capable of providing legal protection for laborers in Indonesia.

The globalization era demands an immediate solution to support long term labor development against impacts from fiscal, monetary, labor social welfare, labor education and training, labor immigration, trade political system, global work structure, and cycle, and legal consequences experienced by laborers or business communities (Arthurs, 2007).

Edward Potter stated that the influence of economic globalization generated the interest of countries to implement sustainable living standards (not only uniform living standards in each country). One should differ between uniform sustainable income standards for each production business in a region with universal welfare. Stephen Pursey from the International Confederation of Free Trade Union or ICFTU also agreed with the idea, declaring that it is unrealistic to expect an exporter from a country with lower per capita income, compared with an advanced industrial country to pay according to equivalent income standards. Furthermore, Ray Marshall believed that the low standards in labor income stem from developing countries attempting to obtain a competitive advantage by suppressing labor welfare (Paust, 1995: 454). Labor income protection for laborers in the import sector receives lower attention compared to their counterparts in export-oriented industry, which drives multinational companies to seek business and production bases in developing countries and then resell the products to developed countries such as United States, Europe, Japan, etc. 
Among numerous labor rights, some of the most concerned and granted ones encompass income, working hours, rights for leave, since it constitutes labor's human rights (Romeo and Sciarra, 1995: 91). Labor development is an integral part of national development implementation to enhance Indonesian human life quality and society. If a non-threatening condition influences economic issues, then the government need not intervene on welfare matters, and that the range of wages between laborers and employees shall simply resort to negotiation methods (Sulaiman, 2016: 267). According to Stanley M. Spracker and Gregory J. Mertz: "... It also establishes standards for the negotiation of collective bargaining agreements, including requirements that all such agreements be in writing and contain stipulation as to hours of work" (Spracker dan Mertz, 1993: 739). For example, the United States applies labor standards for laborers working as much as 40 working hours a week, with holidays on Saturday and Sunday and income consisted of wage, allowance, and social security. General wage (in form of cash), other allowances, leave and share ownership (Sulaiman and Walli: 42). This not including bonuses, weekends, healthcare, and welfare contributions (Covington and Decker: 273).

Aside from that, the company must also provide temporary housing and health facilities for laborers (Fraser, 454-456). Concerning international standard labor rights, the items that were usually deemed important and granted was 4044 working hours per week (Caffrey, 1993: 449) or limitation for laborers working at a company/ employer by allowing laborers to work on an average of 48 hours per week (Ewing, 1996: 129). Leave rights were deemed as human rights for laborers (Romeo and Sciarra, 1995: 91), and company shares ownership benefits provision by shareholders up to $20 \%$ have been utilized to the maximum by laborers (Fischel: 117).

The government has incorporated overall labor income components into labor welfare standard regulation capable of providing labor law protection in Indonesia (Singapore establishes working components such as holidays, working days, wage recipient method, severance, and bonus. The duration of employment is 44 hours per week, overtime between 1-2 hours per day and amounts to 72 working hours in a month, severance payment after working for 5 years, medical allowance provided after working for 6 months limited between 40-60 days per year and hospitalized treatment is unpaid and the holiday is limited to 11 days per year (Surin, 1996: 109).

The utilization of conventional methods whereas companies accept people via announcements establishes the premise that companies require laborers with a pre-determined income. For this matter, the company unilaterally determines 
the wage offered to laborers. These ways should be abandoned to the everchanging conditions, in which the company shall preemptively observe the local labor market to assess the applicable income level. Companies shall not establish the wage below market price since it will not be able to recruit the desired employee and if an income was not agreed upon, then the parties shall resort to customary laws (Subekti and Tjitrosudibio: 367). A sustainable income shall preemptively consider the wage level in the market according to applicable customs. To achieve such income, the level of laborer's income may be established based on mutual agreement born from haggling processes between the laborer and employers (Fossum, 1982: 224). The concept of income assessment is not standalone, since it also prioritizes a professional productive seniority cycle or skilled or productive activity assessment structures (Blanchet: 138).

Welfare level persists on "upper and lower border", and the actual levels between both borders are determined by the interest level from the necessity of the employer to the laborer and interest of the laborer to accept the job and to obtain income to meet his life needs. As such, the level of income determined by joint approval between laborer and employers depends on the ability or strengths of negotiation theory or bargaining power or negotiation may be payable by the employer based on the success of the business, competitive strength (Kertanegoro, 2002: 75). The requirements to conduct negotiation consist of firstly, negotiation depends on the situation where both parties shall obtain benefit from a contract. Secondly, concessions are made by the parties voluntarily. Thirdly, that negotiation should be productive, and Fourthly, that the negotiation used in labor-management relationships are signified by mutual offering. The utilization of collective bargaining theory between laborers and employers is difficult to be implemented since the laborer's bargaining position is extremely weak (Carrizosa, 1988: 290).

The existence of labor demand and offering has generated social deviation., with the existence of "middleman" benefitting of the situation to fraud candidate laborers. Fraud not only occurred during the recruitment phase but also during the placement phase in Indonesia. Since the 1980s, several multinational companies have relocated to Indonesia. There are several attracting and stimulating factors. The stimulating factors are the advanced wage level in industrial states and the elimination of the general System of Prefences or GSP, which constitutes free duty exports to the USA (Sulaiman, 2004: 18).

The stimulating factor is the low income, government stability in controlling the laborers, new order government era which provided 
opportunities for investors to invest their capital in Indonesia with various specific privileges proven by government regulations concerning the request of the investors granted for capital investment purposes along with several concessions such as free duty for raw materials, easing of import duty and exemption of miscellaneous levies for capital goods import.

Labor issues occurring in developing countries continue to persist whether for producer companies for export purposes or various companies engaged in national demands based on a quota system. However, the issues that occur generally comprise low income, absence of freedom to unionize, discrimination against laborers, forced overtime, bad health and work safety conditions, employment termination, long working hours, and lack of rest.

Uruguay Round in 1995 plans to implement international regulation and followed up with ASEAN Free Trade Agreement (AFTA) which shall fully apply in 2007, to create an open ASEAN market. As such, regulation concerning wage policies will need to be readjusted according to the economic and technological development to motivate work achievement improvements (Suziani, 20).

In large, the Uruguay Round attempts to create a better and a fairer International trade system, by considering the economic interest of developing states. The elaboration of Uruguay Rounds encompasses; firstly, ease of market access for export products, and elimination of non-tariff barriers. Secondly, trading of goods and services based on intellectual property rights. Thirdly, role improvement of General Agreement on Trade and Tariff or GATT, (Hansen, 1990: 545). Fourthly, to ease GATT's economic relationship with various related international organizations. Fifthly, National and International level economic cooperation development in trade and economy via International Monetary System.

The impact of globalization was initially considered business as usual by fast-growing Asian countries. However by the end of the 20th century, (Kompas, 1998), globalization has consumed its victims with the demise of authoritarian regimes in Asia with their original assumption that economic growth may be attained with nondemocratic authoritarian or semi-authoritarian models. Such assumptions tend to be faulty since overall globalization especially in the economic field has been dominantly less pleasing towards the treatment of laborers.

The concern for labor standards amidst economic globalization, with the freedom of a company to open branches in multiple countries, has undergone barriers to suppress labor standards or social dumping on labor opinions. The 
solution would consist of; firstly, laborers focusing on export activity, and secondly, the export-oriented company are capable of providing better labor protection by conducting training (Wet: 17).

Free global trade has brought an economic and welfare force including labor welfare (Rosen, 1992: 373). The other advantages are the freedom to predict economic sector interest capable of mobilizing entire trade policies so that there will be lesser massive profit practices as practiced by industrialists in the northern and southern part of United States of America in 1987-1988 (Nollen and Quinn, 1994: 499), which brought loss to low-income laborers.

The economic growth phenomenon also determined the provision of labor welfare warranty. The government plays a role to meet social warranty demands as one of the working welfare components; and this caused multiple companies to shoulder the social warranty costs for nonworking laborers, whose cost was derived from taxes. Such result was possible due to; firstly, varied unemployed laborers. Secondly, limited employment market. Thirdly, the spike in work demand, and fourthly, weakness in economic conditions (Chu, 1989: 640). National development will fail without proper attention to labor development strategies of welfare manifestation in the labor market (Manezas, 1981).

Furthermore, it is observed that the Indonesian economic condition has been plagued with foreign aid and assistance. Aside from that, in the end, that economic globalization has also become a prolonged dilemma. Initial movements by state members of the International Monetary Fund (IMF) did not attempt to increase public welfare but simply targeting political gains. Demands for "right" and "legal" differentiation were to fill the LCA one from rejections as a basis for human rights and positive law (O'Manique, 1992: 383). Law was viewed as an enforcing order made by the public community to protect mankind from unfair treatment of the other.

\section{B. METHODS}

This paper uses normative legal analysis approaches, i.e. legal research carried out by analyzing library documents or secondary evidence as the key task. Normative legal analysis is a scientific research method to discover the facts based on legal scientific reasoning from a normative point of view (Soekanto, 2015: 13-14). Accordingly, this study departs from the perspective of positive legal principles that relate to the national legal framework of legislation (Marzuki, 2016: 59). The legal method and the case approach are the methods used. Secondary evidence is primarily taken from the laws and regulations on 
the eradication of wrongdoing and court rulings as primary legal materials. The data that has been accumulated was then qualitatively analyzed.

\section{RESULTS AND DISCUSSION}

\section{Reformulation of Labor-Management of Demands and Pressure in Income Towards Welfare}

The development of regulations on labor income has become an integral part of national development carried out to improve the quality of life of people and the Indonesian community (Sulaiman, 2016: 266). Joseph Gooding stated that the substance of labor policies focused on the welfare of laborers whose standards are regulated in legislation regarding fair income stands as one of the legal protection warranties for laborers to obtain a sustainable living for themselves and their families (Holloway, 1993: 114).

Along with the progress, the laborer's income became a minimum contractual standard of international labor law based on the basic pattern namely; the provisions in the written constitution (Holloway, 1993: 115). To prevent unfair income standards, therefore a standard law shall be required to protect laborers (Vranken, 1994: 12). As stipulated in regulations, and then adjusted to international customary law. First, the Indonesian constitution, specifically Article 27 paragraph (2) of the 1945 Constitution stated that "Every citizen shall reserve the right to employment and a decent living for humanity". This sentence has yet to reiterate the government's obligation to consider its citizen's need for decent work and livelihoods; therefore, the fifth amendment should have been replaced "The state shall provide decent jobs and livelihoods for humanity"(Hylton, 1966: 141).

To prevent unfair income standards, it is mandatory to promulgate a standard income law (inclusive of wages) that protects laborers. The goal is the completion of labor rights as ordinary people who have human rights or human rights (Vranken, 1994: 12). Therefore, labor matters must be regulated in the constitution, namely Article 28A "Every person has the right to defend his life and livelihood". Hence, the legal positions of laborers have not strictly received their human rights.

Past labor politic was based on Article 27 paragraph (2) and Article 33 paragraph (1) of the 1945 Constitution (Soejono, 1952: 47). or written constitution based on labor point of view, whereas both provisions mentioned the following mandate: the state warrants the work of every citizen, and the state is obliged to 
provide economic needs in the form of decent income to laborers, as an illustration, the state is obliged; Firstly, it grants the right to every citizen to get a job and the state must provide and give work to every citizen. Secondly, that the state shall be obliged to provide income for decent livelihood as the essence of humanity, and consequently the government shall be obliged to provide sustainable livelihoods to its people, and Thirdly, to provide rights for laborers that their contribution shall be granted a higher position than capital and means of production (Sulaiman: 17).

This matter consequently was shifted to the government to maintain that laborers are not viewed simply as a production factor but to consider their dignity and entirety as a human being. As such the labor system must be explicitly regulated in the constitution (Barbieri, 1996: 526). In 1996, Europe had regulated the provisions of the legislation concerning income standard of income, the period of seasonal work (outsourcing), labor rights in the differentiation of the workplace, health and safety standards, hourly wages, and forms of legal options for a mutual agreement between the laborer and the employer (Aaron, 2007).

Thus, the terminology of migrant laborers can be interpreted specifically as a party engaged in a work contract abroad. From a macroeconomic perspective, migrant laborers represent a specific community of the Indonesian workforce to execute Article 28 D paragraph (2) of the 1945 Constitution seeking work abroad. They are development contributors who deserve the government's attention and appreciation since they are nations' ambassadors who risk the nation's name and honor abroad while bringing in incomes (Kompas 25 Maret 2000). Secondly, the stipulation on defined labor regulations; Law No.3 of 1993 concerning Laborers' Social Security or Jamsostek. Law No. 13 of 2003 concerning Labor, Law No. 20 of 2004 concerning Trade Unions/Labor Unions, and Law No. 40 of 2004 concerning National Social Security.

Facilities provided in Law No. 13 of 2003 concerning Manpower, namely; Trade unions/labor unions, labor organizations, bipartite cooperation institutions, tripartite cooperation institutions, company regulations, collective labor agreements, institutions for organizing industrial relations disputes, labor and family rights receive labor social security. Concerning the existence of trade unions/labor unions, each laborer has the right to become a labor member, to form a trade union/labor union, and the funding/costs of labor members and/or trade union/ labor union are borne by the laborer.

Based on the purpose, that enforcing compelling legal regulations can be divided into two kinds; Firstly, the regulation that is capable of protecting 
laborers so long as laborers are still bound in an employment relationship. Secondly, labor laws shall provide labor social security.

Similar issues were stated in Law Number No. 39 the Year 1999 concerning Human Rights in Article 38 as follows:

a. Every citizen following their talents, skills, and abilities, is entitled to decent work.

b. Every person shall reserve the right to freely choose the desired work and entitled to fair labor conditions.

c. Every person, both men, and women conducting the same, equal, equal or similar work, is entitled to the same income and terms of the employment agreement; and every person, both male, and female, in carrying out work commensurate with the dignity of his humanity is entitled to a fair wage following his/her achievements and able to warrant the survival of his family.

To create a warranty, the protection must prioritize fairness in essence regarding labor income; as such the sole requirement is to obtain an agreement free of pressure and duress then the only document required is an agreement without pressure and coercion strictly between laborers and employers to pave the way into an income agreement. This fact justified that the evaluation of labor income standards underlines the need for collective bargaining between laborers and employers (Zifchak, 1983: 4);

"The strength of collective bargaining is that every bargaining relationship, much like a marriage, is sui generis: collective bargaining allows the parties in each relationship to structure that relationship according to their unique mutuality of interest. Particularly in this field, therefore, it is overly simplistic to strain to find trends with the universal application".

Restrictions on the determination of permitted labor standards were conducted by suppressing bargaining collective (joint negotiation) between laborers and employers so that the process of collective bargaining (laborers and employers) to take a good ("proper") role in carrying out labor fairly (fairly) in terms of labor law. The government's interference in determining labor income acts as an exception or compulsion because the government is obliged to maintain political stability from the order and to stabilize economic conditions from the economic crisis. This was verified in the "Laissez-Faire" doctrine. "LaissezFaire" philosophy has warranted the income for laborers since the labor piping union in England has accepted the Laissez-Faire to limit unskilled laborers by the beginning of 1999 (Lord Wedderburn FBA, 2008: 40). 
Furthermore, the solution to resolve such an issue is to enact concrete steps, among others: Firstly, the parties involved should remain consequential with labor policies and economic policies through several negotiations. Negotiation policy produces "Sui-Generis", which is a pattern obtained from several existing ones and certainly not in a simplified sense. One must attend the interest of laborers an agreement concerning income among the industrial sectors of the like. And then to increase the frequency of income regularly, and implement income adjustments nationally at the local level, all of which is achieved by mutual agreement. Secondly, the Government directs economic politics to encourage company leaders and laborers on perceptions in the economic field, namely from the basis of courage to entrepreneur to provide job security for laborers. Thirdly, to use political economy philosophy which causes a process of collective bargaining to take a positive role for laborers in realizing a sense of fairness from the perspective of labor law. If there is a conflict or dispute between laborers and the company even though there is a voluntary agreement, then collective bargaining can be taken as a method to achieve mutual perception.

\section{Pressure Concerning Income based on International Labor Standards}

Labor pressure had originated from international labor organizations or the International Labor Organization (ILO). After concluding more than 170 agreements, the existence of ILO, with its initial organization phase in Washington D.C. (1919) has created a protection system for labor' rights. The utilized standard requires each of its members to consider ratification and enter into an agreement. The agreement covers the scope of individual and collective rights of laborers and company owners (Hartley; Rosen; Abraham, 1994: 2). Among others, the most important is an agreement where several countries may compete due to labor exploitation.

Specifically for Indonesia, which was immediately under international pressure from the ILO when Indonesia registered into the organization in 1950. Then RI had ratified, inter alia; Convention No. 100 of 1951 concerning The Payment of Male and Female Laborers for Work Of Equal Value, Law No.49 of 1954 concerning Approval of ILO Convention No. 89 of 1949 concerning the Application of the Fundamentals of the Right to Organize and Collective Bargaining, Law No. 18 of 1956 concerning the Approval of ILO Conventions No.80 of 1957. 
The current economic development capable of supporting industrial development became a common view in East Asia countries such as Hongkong, Singapore, South Korea, and Taiwan against the economic-political structure which involves numerous state involvement in contracts with state institutions. These practices benefit the private sector, thus the equilibrium between national economic control and international economic relationship can be maintained with the international trading system. Then, the desire of a trade organization called the WTO, then since 1992 has established a standard component of laborers who provide high incomes including labor social welfare among western European laborers or MEEs. There are still several European countries which still retain the tendency to suppress low incomes given to laborers such as Greece and Portugal (Erickson; and Kuruvilla, 1994: 29), so they were given the threat that they would be disbarred from the EEC membership or the European Economic Community if they remain persisted on carrying out social dumping on their labor standards. So the determination of minimum wage as part of income in the United States have already included 40 working hours a week, excluding other payments (Cunningham; and Llorens, 1993: 412) such as; firstly, regular day overtime, Sunday overtime, rest day for 6/7 working days, Secondly, premium (Covington; and Decker: 273). Thirdly, lunch is not included with bonuses, time off, health costs, and welfare contributions.

The United States free trade system or the North American Free Trade or NAFTA (Nollen; and Quinn, 1988: 3), stipulates that provision of minimum income from all income granted for laborers is one of the laborer protection methods from social dumping via supervision through the determination of labor standards (Erickson; and Mitchell, 1996: 763), the socio-political treatment of the government for laborers employed in the industrial sector (Midford, 1994: 535).

On the other hand, the employer has no authority to force laborers to work on holidays and/or Saturdays (Blanchet: 126), despite the persuasion with high overtime pay and all accommodation fees paid for by the company, so long as there is no agreement between laborer and employer overseen by the supervisory official. Including the income granted to laborers engaged in textile and garment industry sectors in Kuala Lumpur state, Malaysia in 1990 with around 1000 companies with export destination to the USA and Europe (Hassan: 116). Besides, that the comparative study shows that trained laborers receive higher wages compared to their untrained counterparts.

The difference of income (Strauss; and Sayles, 1990: 3) between professional and highly skilled laborers compared to their untrained 
counterparts had been reflected more on a seniority basis for workforces aged between 20 until 60 years old, generating competition between those capable of doing so, motivating enhanced work productivity including production on a much better/finer scale.

Similarly, the difference in income does not only translate that laborers with good work abilities and English communication skills enjoy high incomes (Biagi, 1994: 302), while laborers with low skills will end up with low income. Howeverlaborers with English proficiency in communication needs for business purposes shall also determine the degree of income granted (Player, 1992: 120).

One of the organizations actively applying internal pressure regarding bipartite labor in Indonesia is the Indonesian Sportshoes Monitoring Network (ISMN) Jakarta, which has conducted company control and monitoring, especially multinational companies which treated their laborers by violating general human rights and international labor standards, because in Indonesia companies often neglected the Code of Conduct, generating multiple problems such as deviations of human rights and unfair treatment despite existing laws and regulations (Sulaiman, 2003: 221). For example, the provision of wages below the Minimum Provincial Wage (UMP), while companies enjoying great profits, discrimination practices between male and female laborers, companies employing minors to become factory laborers, long working hours, unhealthy working conditions from a physical or mental perspective, such as inadequate sanitation, sexual harassment, manipulation of consumers by using advertising services or promises of non-slavery in the factory. The aim is to control deviant companies, to apply the company's code of conduct following the agreements made for the improvement of the lives of their laborers. Another goal is to build a system that guarantees consumers that their products are not made from sweatshops. If under pressure, companies can reject regulations concerning labor. If they refuse, they will get a reaction from the laborers in the form of objections or strikes which can result in a one-sided dismissal.

Supervision by the United States is inseparable from the International Monetary Fund (IMF) financial institutions which have provided financial loans and guarantees to Indonesia. One of the terms of such loan from IMF was that the fund shall not be used for human rights violation activity (Cerna, 1994: 740), as practiced by the Old and New Order government, therefore Indonesia is no longer allowed to practice violations of normative rights because such act violates labor rights.

The human rights of laborers based on the 1980 trade commission on standard international agreements have ratified an agreement which includes; 
Firstly, the right to establish an association. Secondly, the right to organize and trade effectively. Thirdly, the prohibition of using violence and pressure against laborers. Fourthly, the stipulation of a prohibition on employing a minimum age of labor. Fifthly, tolerable working conditions can be tolerated by providing minimum wages, working hours, security, and health guarantees.

The Urina Declaration (Austria) at the World Human Rights Conference on 25 June 1993 as an implementation of universal human rights on 10 December 1948 (Caire, 1994). The Urina echoed has the statement that all human rights such as basic human rights, in terms of; individuals, political, economic, social, and cultural rights must be implemented simultaneously and none of these rights must take precedence before each other; in other words labor rights are carried out simultaneously including labor rights. The Urina Declaration (Alston, 1993: 30) is used as a guideline for the association, political, economic and social, cultural rights.

Based on monitoring from ISMN, the provisions governing laborers in Indonesia often cast the Code of Conduct aside, generating many problems such as deviations of human rights and unfair treatment despite existing laws and regulations. For example, the provision of wages under the Regional Minimum Wage (UMR), while the profits earned by the company were enormously high, the company employs children to become factory laborers, long working hours, physically and psychologically unhealthy working conditions such as inadequate sanitation, sexual harassment, consumer manipulation by utilizing advertising services or promises refraining from slavery practices in the factory.

In 1991, back in the United States of America or USA, the term "minimal standard contract" was disputed, for example in the case of Lechmere, Inc. $v$ National Labor Relations Board who challenged the minimum legal provisions of 4.25 U.S. dollars per hour in association with federal labor law Section 8 (a), (3), whereas due to unclear labor application that employers tend to discriminate in the form of hired labor or another labor status, even though there exists a labor organization (Hylton, 1996: 1751). For employers, such application was based on the understanding cohesive strategies, since there are employers who are unable to maintain when there is labor unrest pressuring its company (Hayashi, 1992: 207). Meanwhile, laborers in respective multinational companies each apply a variety of uses of laborer types (Anoraga, 2000: 117).

In Indonesia, the enactment of minimum income is regulated directly by the government, since the position of laborers is still vulnerable. The fact is that income is an essential component to sustain both the labor and his/her family. The idle workforce is vastly outnumbered by the available jobs available, leaving 
employers in a position to determine their desired wage levels. If the laborers declined, then employers shall utilize various tactics to dismiss such person and replace them with other job seekers.

Labor issues in some developing countries retained several different varieties. However, several but the point is that the problems faced include extremely low wages. Other problems namely; lack of freedom of association, discrimination against laborers, forced overtime, poor health, and job security. Besides, problems often found in industrial companies range from poor work safety, work termination, long working hours and lack of rest, target system (quota system), machine-related accidents, and fire (Brookes; and Madden, 1995: 18.). Overcoming threats from developed countries and the ILO concerning "social dumping" may become some of the inhibiting factors which could hamper Indonesia's exports to the United States and Europe. Respect for labor rights should be based on international income standards, supported by clear norms and criteria. Otherwise, Indonesia is considered to breach human rights.

According to Edward Potter that the minimum standard required by international labor organizations is a contract that was born from the mutual will of the laborer and the employer. Thus the contract should not be a uniform minimum standard contract labor in each country. It must be distinguished between the uniform minimum income of each type of production business in an area with a universal minimum income. Stephen Pursey from the International Confederation of Free Trade Union or ICFTU reiterated that it is unrealistic to expect an exporter from a country with lower per capita income, compared with an advanced industrial country to pay according to equivalent income standards. Furthermore, Ray Marshall believed that the low standards in labor income derive the condition of under developing country (Paust, 1995: 454), attempting to obtain a competitive advantage by suppressing labor welfare and under duress.

Han Goral Myrdal then clarified that the employer desired to determine the minimum labor standards, thus raising the need for legislation on wage and income standards as part of the employer's costs for labor, such as; uniform wages and income, $\mathrm{u}$ benefits, guarantees for laborers' safety and health, provisions concerning labor contracts for laborers in the type of business in the labor's and company domicile. The understanding of the contract herein discusses annual issues such as shares, gratuities, or other forms of bonuses. So it is not an annual contract in the form of outsourcing laborers that have been applied by the Government of Indonesia, initiated based on the decision of the Minister of Manpower of the Republic of Indonesia. 
Fundamentally, the problem of labor income protection began with Adam Smith's review (1776) stating that laborers' remuneration was based on supply and demand or "Legal Theory of Supply and Demand". In such provisions, that the determination of the provisions of labor income depends on the results of mutual agreement made by both parties, namely laborers and employers with different positions. The laborer's desire to obtain a balanced income is determined by supply and demand. Next Smith informed that the standard calculation of minimum labor income or poor laborers in the provision of "income" wages (Zifchak, 1983: 4) to grant sustainable livelihood for the laborers with two children and his wife.

In the reviews above, John A. Fossum complemented it with "bargaining theory". The theory of negotiation stated that "There are upper and lower limits for income levels". The actuality level between the two boundaries shall be determined by the degree of importance of the employers' needs to laborers and the interests of the laborer to accept such work, so they can earn income to meet the daily necessities. Therefore, the level of income determined by the mutual agreement between the laborer and employer depends on the ability or bargaining power or negotiation. Afterward, the cross offers a special set of characters to explain the negotiations: firstly, negotiations apply in a situation where both parties will benefit from an agreement. Secondly, concessions (leeways) made by the parties aside from negotiations shall be carried out voluntarily. Thirdly, negotiations must proceed productively (Fossum: 214), and Fourthly, negotiations used in labor-management relations shall be marked by oral and written requests and leeways.

Furthermore, obtaining labor market characteristics will generate an impact if labor demand in the company is inelastic; costs will increase correspondingly with the size of the labor force. If the laborers with a similar amount and specific skills fit the company demand with average income relevant to the competitors, then income raise shall become necessary to leverage the offer (Rajagukguk, 1993). Should there be a sole company that raises the income level, then it is viable to increase the number of laborers to expand the market. But to increase market supply, each company will have to increase its offer.

The state at times may be required to intervene on behalf of the weak, by establishing minimum income standards. William E. Brock stated that the state or government must develop a robust collaboration from the concept of glorified labor and equality based on a mutual collective offer of both parties which render it possible for trade unions and management (companies) to maintain individual integrity while working for every party's benefit. The government is capable to 
encourage cooperation between management and laborers to maintain economic competitiveness. Therefore, it should also strengthen its commitment to the integrity of individuals both laborers and management deemed vital or the principle of collective bargaining, so that labor costs can increase (Glick, 1989: 219). This concept in determining minimum standards does not stand alone but also prioritizes the seniority cycle (Blanchet: 138) professional productivity or skill or the structure of the assessment of productive life.

Based on a sense of joint ownership between employers and laborers in advancing companies with a lifetime employment status (Gemeinschaft doctrine) for the success or failure in the production process derived from the Japanese labor system, it is imperative for the state to participate and maintain the transparency of its company' financial condition, private companies (private national and local private companies)) and the distribution of shares to laborers to be determined in the contract. Therefore, the income shall be determined based on the costs required to maintain or restore the laborers to keep working continuously with the fulfillment of all the needs of his family (Ballon, 1988: 123). Labor income standards are determined by the quality of labor resources and internship and the company's internal promotion (Araki, 1994: 145). Thus between laborers employed in national private companies and foreign companies, there are no significant differences in income issues (Sulaiman, 2006), since such income has fulfilled the need for a proper living.

If the labor and management (company) cooperation program simply aims to equalize the path between laborers and companies, it will weaken the collective bargaining process. Because employers think that every laborer in making proposals to improve welfare shall be sufficiently represented by the union (Glick: 220). The role of labor organizations is very limited to only struggling for general labor protections such as wages, hours of work or overtime, replacement of transportation costs, bonuses, premiums, and others, which is liable to be negotiated with the appropriate bidding partners. In the regulation concerning trade unions/labor unions (based on Law No.21 of 2000), the labor is not obliged to become a member or nop there is no labor obligation to become a member or not become a member of a trade union, thus the laborers are free to negotiate their income.

Furthermore, stating that if the government or the Ministry of Manpower has encouraged cooperation between management and laborers to maintain economic competitiveness, the government must also fortify its commitment to personal integrity of individuals, both laborers and management deemed vital or the principle for collective bargaining, so that labor wages can increase. 
Lack of freedom of association, discrimination against laborers, forced overtime, poor work health and safety, termination of employment, long hours of work, lack of rest, quota system (target system), workplace accidents are problems that often strike laborers. With regards to external threats, such as those from developed countries and international labor organizations (International Labor Organization) relating to "social dumping", such incidents may impede export activities to the United States and Europe (Alston: 26). International efforts to gain the respect of human rights should be based on internationally recognized income standards. Laborers in developing countries continue to be vulnerable in wage negotiations. In terms of having two advantages, namely: first, the state can develop domestic industries by protecting markets or rising prices for foreign competition. Second, the state uses trade barriers to protect the age of domestic industries and to block market access from foreign rivals, and protect the existence of industry (Stutzman, 1993: 136). Government policies should also be realized based on legislation to enforce human rights standards. There must be accountable, clear, and explicit norms and criteria to refrain from violating human rights. Because a country that fails to provide wages according to international standards is considered to have violated labor rights (Alston: 26). Furthermore, the labor wage standards that have been outlined in international trade represents the standard wage (minimum), working hours, and labor safety and health guarantees.

The conduct of hiring laborers below the minimum income is a form of labor rights violation. The Declaration of World Human Rights on December 10, 1948, and the World Human Rights Conference on June 25, 1993, have called on countries that violate labor rights such as; China, Colombia, Indonesia, Iran, Iraq, Mexico, Myanmar, Pakistan, Singapore, Syria, Vietnam, and Yemen to determine internationally accepted standard wages. The conclusion declares that the main dispute of international law contents (Cerna, 1994: 740), since such act includes violations of labor rights such as all human rights (Caire: 297), such as fundamental rights; individuals, political, economic, social and cultural rights which must be implemented simultaneously.

Labor' rights in the United States, Britain, and Europe over the past twelve years have been the foremost to demands changes in labor relations. In England, trade unions are ensnared by the rule of law that binds collectively in every internal decision and the great influence of parliament which then spreads to states such as; France, Germany, Sweden, and Italy. In the United States, such an attack came from groups of company owners and private business associations wanting to disband the trade unions. The United States and Canada succeeded in revising the 1971 industrial relations law (Summers, 1992: 157) so 
that the Federal Court intervened by appointment from the President and with the advice of the Senate to resolve anti-union disputes.

Some of the factors desired by foreign investors coming to Indonesia are security and comfort. If security in trading is guaranteed, then comfort is created in doing business, so companies can race to produce their industries, both import activities and export activities abroad, including for example exports to the United States States, European countries, and other developed countries. It is also no longer heard of the country's pressure with the threat of social dumping on Indonesian products, nor is there any demand from international labor organizations or the International Labor Organization (ILO) that demanded Indonesia to stop human rights violations in the labor wage sector.

Labor legislation in the United Kingdom since 40 years past (1967) adopted an understanding of capitalism; Firstly, the labor system of the monarchial pattern is flawed. Secondly, the standard model of employment contracts in the UK and Italy tends to promote a sense of justice. Thirdly, consideration of the European pattern of employers via 'freedom of which employers', in which employers may exercise the freedom to retains social rights and termination of its laborers (Wedderburn, 2007: 36). Europe possesses 15 pioneer countries as mentioned by Paul Davies and Markus Freedlang, aside from Britain which was changing the collective negotiations that had given special priority to the rule of labor regulations.

There are three ways to develop new world labor (before acts of arbitrariness) namely; Firstly, to simplify and shorten the time of labor problems resolution as pioneered by Denning; Secondly, to apply individual labor contracts, and; Thirdly, to embrace a free economy as done by Europeans on the role of trade unions in solving court cases.

Labor law reforms are laden with influences of globalization, starting from England, Spain, and the Netherlands. Prof. McCallum (Australia) informed that labor legislation is influenced by economic globalization, as well as individual negotiations led by collective bargaining between employers and laborers. After developing from Europe then such reform extended to the United States and Eastern Europe, according to Richard Lambert that globalization has been heavily exposed to capitalism and technology.

In Italia, Ludovico Barassi pioneered in 1901 with the slogan "Contratto di Layoro" (Employment Contract) that examines private labor law which is capable of implementing and accepting collective bargaining, globalization, and adjustment of labor law in the modern state. 
The modernization of European labor legislation was notably spearheaded by the European Commission in 2006, which was implemented in Sweden, Germany, Britain, and Denmark in 2007 that included social security. Simon Deakin and Frank Wilkinson suggested that labor law policies prioritize social rights, Yusuf Stiglitz and Hepple voiced out that the expectations of globalization were pioneered by the World Bank and the IMF as drivers of globalization. However, the barriers or restrictions on global labor benchmarks were not easily hidden, because they are obliged to adopt for long-term framework influenced by economic considerations, social conditions, and human resources. According to Tarashi Araki (Tarashi Araki, 2007: 28); Firstly, the Japanese labor law system is unique as opposed to the labor system in Europe and the United States, since it attempts to adopt foreign laws which in turn influences the legislation and legal theory. Secondly, Japan's labor relations prioritize labor security and internal flexibility, the characteristics of decentralized development relations brought under the authority of corporate unions, and Thirdly, adjusting the combination of individual labor and collective labor system.

Japanese traditional contract theory rejects modification and adaptation from outside Japan. However, laborers desired that the traditional Japanese labor system in the form of contracts be able to face and seek a solution in the interests of competition, including for future purposes. The Judge's decision on the contract which generates dismissal is viewed as an act of harassment.

The decentralization/autonomy of Japanese companies also supported the labor system because both union companies and individual companies referred to collective agreements. Japanese businessmen also established labor cooperatives in their group business environments under the control of company management. This practice was based on the economic growth of laborers that began in 1950-1960 due to World War II so that laborers and employers can jointly rediscover the traditional Japanese labor patterns.

The profits of such cooperatives are distributed to the laborers. If the cooperatives prosper, its benefits shall also extend to the laborers, to create a sense of mutual need between the laborers and employers both short term and long term including lifetime employment of labor system. In Japan, both laborers and management gradually transformed from what was categorized as separate, separate (not compact) units into a sense of togetherness because both parties (businessman and laborer) have benefited together.

Comparative study on the implementation of decentralization in industrial relations negotiations between the United States and Europe with 
Japan has revealed a fundamental difference. But the point is that such an act was to be able to provide legal protection for working conditions and high morale and increase company production (harmonious company organization) up by around 20 percent.

The labor law issues with company management in the relationship of economic growth have been ongoing for 46 years in Europe according to Kerr, Donlop, Harbison, and Myers (Weiss, 2007), that the application of ancient labor patterns with the globalization approach by Kerr was said to have changed due to the influence of monetary pressures and fiscal or simple globalization criteria.

The government has created a climate where no institution command absolute respect by both parties, but also infused interplay between employers and trade unions themselves some national labor law is far more complex as opposed to labor law through the globalization approach of "Labor Law and Global Trade". Furthermore, empirical research on telecommunications industry company laborers demonstrates that developing countries (northern countries) laborers where both labor conditions, labor unions, training, compensation, and company management are still in a disappointing condition arising from repeated violations of providing laborers with adequate livelihoods as stated by Bamber, Lansbury, and Wailes. If employers failed to grant essential and fundamental rights for laborers such as wages by employers as stated above, then the only effective weapon possessed by laborers is to conduct a strike. Labor strikes can no longer be suppressed by the government or employers, even more so in the era of transparency or globalization, where there is no longer a country capable of covering up labor rights abuses that violate human rights. This is because there is an existing control from neutral non-governmental organizations, including supervision of developed countries including for example the United States.

The international pressure of institutions such as the International Labor Organization (ILO) on Indonesia, plays a very important role in disputing the reasons for an extremely low labor wage system that is not based on mutual agreement and consideration of labor rights and international pressure on trade competition. However states that such practice is not following the Original Treating Market philosophy, because the philosophy is directing competition by companies which lies within the state's responsibility regarding low wage labor but remains influenced by market forces. This is still happening in developing countries, including Eastern Europe. The pressure of globalization which has set minimum standards from the ILO (Bercusson, 1995: 7) is reinforced by Hepple that labor law remains heavily influenced by global developments. 
The benchmark minimum standards consisted of decent income, health and safety, work time, and other benefits. Since 1996, the EU has entrusted the PostingLaborers Directive to determine labor protection standards in the form of delivery; wages/salaries, overtime, vacation/minimum payment reimbursement, health and safety, etc. However, even these grants have not been maximized and have not satisfied the laborers in France and the Netherlands.

Co-involvement of labor together with management (employers) in decision making has been practiced in Germany, Australia, the Netherlands, and Luxembourg with a dual system structure, where laborers and companies (management) engaged in decision making is either an unionized/ individual enterprise or a group of national/regional/companies international, according to Brian Bercusson. The fact is that the entry or absence of laborers in a trade union is very difficult to separate due to the legal position of an important trade union with an advanced bargaining position in comparison to individual laborers. This is a consideration; firstly, trade unions are organizations of laborers' shelter themselves such as in France, Greece, Portugal, Spain, Scandinavian countries and secondly, for a long term, management decisions are considered taboo if laborers are not involved by labor organizations to find common organizational attitudes (for laborers and employers) between the EU from different countries adhered to Ireland, Britain, and Italy.

Minimum labor standards in European member states have been enhanced since 1970-2002, in the form of health and safety warranties, pioneered by the United Kingdom which started labor rights consultancy services. The form of absolute consultation includes the following conditions; Firstly, by considering the time, calculation methods, substantial rights/essential laborers, and effective ways of managing laborers. Secondly, the company shall provide reliable consultation and infrastructure facilities. Thirdly, labor representatives shall reserve the right to propose and formulate labor interests facilitated by employers. Fourthly, the laborer representative shall reserve the right to be granted a reply by the employer on the proposals and input of the laborers, and Fifthly, the joint decision of the employer/management shall be signed as proof of validity.

In the EU there are 4 (four) large collectives as a labor information center on company management namely; Firstly, an amalgamation of several companies. Secondly, by forming a parent company group. Thirdly, the formation of branches in the parent group or branching out into several other group branches within the European Union, and fourthly, information gathering from the association of several internal EU companies. 
Another internal pressure that concerns bipartite laborers in Indonesia in determining income is the Indonesian Sportshoes Monitoring Network (ISMN), that the provisions governing labor in Indonesia that often sidelined the Code of Conduct, triggering many problems, such as deviations from human rights and mistreatment despite existing laws and regulations (Sulaiman, 2003: 32). For example, wage provision of wages under the UMP standards, while profits are very high, discrimination between male and female laborers, companies employing underage children to become factory laborers, long working hours, physically and psychologically unhealthy working conditions such as inadequate sanitation, sexual harassment, customer manipulation by using advertising services or false promises and the slavery methods in the factory.

\section{Pressure for Income Acceptance as Labor Welfare Facility}

Law No.13 of 2003 on Manpower has yet to regulate employee protection, let alone income protection to laborers since it does not limit the wage component, explicitly emphasize the decentralization of income, clearly regulate the determination of labor wages preceded by an agreement process between the union and the employer, criteria available for the employer, so that such party is permitted to exclude wage provision to his laborers.

From around 110 million laborers employed in 2008, 70.22 million were categorized as blue-collar laborers, while 24.73 million were white-collar laborers (relying upon the intellectual ability to earn a living), while the rest were in the normal category. Because the laborer has not been trained and educated, bluecollar laborers usually ended up in a lesser position compared to the company. Not only regarding wages but also other laborers' normative rights, such as social security, health insurance, and old-age insurance, as well as other rights. (Peradilan, 1993).

The level of labor income in Indonesia is lower compared to developed countries, including countries in the Southeast Asia region or the Association of South East of Asian Nations (ASEAN) except for Vietnam. Alfredo Sanches Carrizosa believed that states with the tendency of lower labor income levels were due to income determination conditions which were borne not through collective bargaining or negotiation or joint approval (Kompas, 2001), and there is no negotiation between laborers and employers, so there are no agreements that can be binding between both parties (Carrizosa: 299). It also explains why labor costs in Indonesia are so low. Furthermore, Carrizosa stated that the bargaining position of laborers in Indonesia is extremely weak, so that the amount of labor 
income was regulated by certain rules, and collective agreements would fail to apply.

According to Narendra Pani that India as a developing country has long utilized the political democracy principle, but still fails to implement labor democracy. India is unable to regulate its laborers like other developed countries or authoritarian countries do. This makes India a less attractive destination for foreign investors and making all Indian products in "a softer" manner than products produced by other competing countries that apply labor standards (Suziani: 31). Labor problems in developing countries consist of low wages, lack of freedom of association, labor discrimination, forced overtime, laborers' health and safety, layoffs, target systems, machine and accident accidents. A free system for collective bargaining without government intervention, and individual labor contracts/agreements (Lord Wedderburn FBA, 1988, including Bomer Pasaribu, former Mennaker and Director of the Center for Labor and Development Studies (CLDS)) who stated that inventory of products found in labor regulations in the form of ministerial decrees, ministerial regulations, joint agreement letters with the total 197 has been found. Of all the amount, all is beneficial for employers or non align with laborers (Kompas, 5 July 2001)

The emergence of various demands is related to numerous Conventions such as; ILO Convention No.26 of 1930 concerning the determination of minimum wages. ILO Convention No.52 of 1939 concerning 6 days off every year. ILO Convention No.95 of 1952 concerning the protection of wages/"income" paid by currency in the origin country of laborers. ILO Convention No.99 of 1952 determination of the income of agricultural laborers. ILO Convention No.100 of 1953 concerning equal income between male and female laborers in the same company, and most recently ILO Convention No.131 of 1970 concerning setting minimum wages of equal value (Sulaiman, 2006: 26).

As a result of the demands by laborers for income regulation, in 1957 the Government of Indonesia was forced to ratify ILO Convention No. 100 of 1951 (the Republic of Indonesia, Law No.80 of 1957 concerning the Approval of the ILO Convention No.100 on Wages for Male and Female Laborers for the same Work). The application of ILO Convention No. 100 has been ratified in the existence of a labor organization known as the All Indonesia Laborers Union (SPSI) which employs a minimum of 25 people required to form SPSI (S. Arieff, 1986). Labor income standards in forming trade unions, only listed procedures for forming and registering trade unions (Sherman; and Lucia, 1992: 56). The government has formed a Bipartite and Tripartite structure which is expected to bridge the relationship between laborers or labor organizations and employers, 
giving birth to PP No. 8 of 1981 concerning "Protection of Wages". Then, the conventions which have been ratified by the government namely; Law No.19 of 1999 concerning Ratification of the ILO Convention No.105 concerning the Abolition of Forced Labor (ILO convention on the Elimination of Forced Labor), Law No.20 of 1999 concerning Ratification of the ILO Convention No.138 Concerning Minimum Age for Admission to Employment (ILO Convention Concerning Minimum Age to employment) Law No.21 of 1999 concerning Ratification of Convention No.111 Concerning Discrimination in Respect of Employment and Occupation (ILO Convention Concerning Discrimination in Employment and Occupation).

Meanwhile, Collective Labor Agreement is achieved through a bargaining process between the government and employers, with trade unions (labor organizations), the General Comprehension of the International Labor Organization, Law No. 21 of 1954 concerning Labor Agreements between Trade Unions and Employers, Law No.3 of 1961 concerning the Approval of the Convention on International Labor Organization No.106, Law No.3 of 1969 concerning the Approval of the Convention on Hygiene Labor Organizations in Trade and Offices following ILO Convention No.120

The Indonesian laborers believe that the UMP granted by the company in the workplace is insufficient or even improper, with a belief of mistreatment, and this condition has slighted their human rights, which then generated labor resistance in form of demands and even developing into strikes due to wage problem (Kompas, 2001). Laborers are liable to conduct strikes since the ban has not to be revoked and there is no legal guarantee for laborers if they are terminated. In the event of a crisis, therefore the Government should take steps to seek joint independent agreement between labor organizations (union) with trade unions (employers). If the parties failed to achieve a mutual wage agreement which leads to labor strikes in general company, then business owners are urged to continue employing the laborers.

\section{Labour Court in Indonesia Welfare System}

Labor settlement in Indonesia is regulated by Law No. 2 of 2004 concerning Settlement of Industrial Relations Disputes (PPHI) divided into settlements (Sulaiman, Labor Court, 2006: 21.); Firstly, rights settlement. Secondly, the settlement of interests. Thirdly, settlement of employment termination, and Fourthly, a settlement between trade unions/labor unions in only one company. These peaceful settlements are classified as internal. In PPHI this is known as an 
amicable or out of court settlement. The peaceful settlement is known as settlement through conciliation, mediation, and arbitration. Also, the provisions of arbitration are regulated in Law No.30 of 1999 concerning the Arbitration and Alternative Dispute Resolution.

The existing Arbitration Board in Indonesia is represented by the Indonesian National Arbitration Board (BANI) which stipulates, inter alia; "All disputes arising from the agreement will be resolved in the first and last stages according to the BANI procedure rules by arbitration appointed according to these regulations (Komar Kantaatmadja, 1989: 4). Law No. 30 of 1999 concerning Alternative Arbitration of Dispute Resolution (AAPS) listed the role of the Indonesian Court to strengthen the arbitration process from the beginning until the implementation of the arbitration award (Rajagukguk, 2000: 9). Article 11 paragraph (1) of Law No.30 of 1999 stated that a written arbitration agreement shall negate the right of the parties to submit disputes or disagreements contained in the agreement to the District Court, and paragraph (2) states that the District Court must refuse and shall not intervene in dispute settlement that has been determined through arbitration, except in certain cases stipulated in this law.

The role of the court to develop arbitration is visible from Article 13 to Article 72. Article 13 paragraph (1) for example, states that "If the parties are unable to reach an agreement regarding the selection of arbitrators or no provisions are made regarding the selection of arbitrators", Chairperson of the District Court shall appoint the arbitrator or the arbitral tribunal. Article 72 paragraph (4) opens the possibility of an appeal from the District Court which can be appealed to the Supreme Court which decides in the first and last instance. This arbitration law does not regulate labor arbitration, thus such a legal position is disadvantaging laborers when settling disputes with employers regarding labor wages.

The role of labor arbitration should ideally be applied in labor disputes since labor arbitration has a basic concept; firstly, determining the company's authority achieved through collective bargaining agreements. Secondly, to determine the authority of the arbitration itself, that is needed to be able to adjust the interests of laborers and employers. It is this fundamental observance that measures the degree of employment agreement compliance.

Labor court to resolve disputes is considered a drawback in the labor fields if the arbitration mechanism is not used in labor dispute settlement because arbitration settlement is expeditious enough to be accepted by laborers and employers. David Feller states that since 1950, especially the late 1960s and 1970s 
both traditional and trade unions that are related to the interests of the globalization of the domestic market in industrial companies preferred labor arbitration (Fietbrict: 275). Many rallies and strikes indicate the ineffectiveness of labor legislation for trade unions, therefore they expect arbitration to play a greater role. This is where the labor legislation functions to regulate dispute resolution using the arbitration method.

Labor disputes settlement through arbitration, each party (employers and trade unions) shall submit their case with all the supporting arguments and evidence, including statements in the form of documents. The arbitrator then presents socially just, economically sound decisions, and in the interests of both disputing parties. For example in the United States, multiple disputes and frequent meetings of the arbitration council have led to the creation of industrial or labor courts (Dilts: 81). This court is more permanent compared to the arbitration council which was usually formed to handle certain disputes, and after then dissolved or disbanded after completing its duties (Kompas, 2001). In $\mathrm{KKB}$, trade unions and employers shall agree to submit any disputes to the arbitration or industrial court. Before ensuring the occurrence of disputes, both parties are required to exhaust every effort to reach an agreement. If the court is established in a state, then the ability to prepare and present all forms of labor disputes in the well-documented form shall be an important statement for trade union leadership.

The imposition of labor legislation renewal has continued for the past 40 years, even according to Otto Kahn-Freund because there has been a decline left by a company representative in charge of the correlations between capital and labor in industrial society. "Laisser Faire" consideration became Paddy Ireland's state of a point where company law shall develop, including when there is a conflict/dispute, using labor arbitration.

Labor legislation of the 1950s in social and economic considerations regulated in collective bargaining cannot grant employers with the authority to indiscriminate labor dismissal, since it has been categorized as a human rights violation in the labor sector. Also, labor rights as a sense of company ownership shall be given the right to share ownership.

Despite the disagreement by a pipe trade union to "Laissez Faire" doctrine, since the pipe sector laborers were proven to be trained laborers, the 2004 ILO legislation along with the Italian labor constitution and legislation from since 1970 have accumulated human rights adopted for Labor freedom to form a trade union. 
European labor laws and regulations have opened wide economic space to cater to internal markets; Silvana Sciarra stated that labor justice and labor arbitration should create a balance between the laborer's social conditions and employer's freedom to determine the desired labor market. The purpose of arbitration as an alternative dispute resolution will be in vain if the court is still willing to examine such a dispute. However, the court plays a large role in developing arbitration, when such a process requires court intervention, to expedite the arbitration process itself. The court also functions to ensure that the arbitration process and award is not based on false evidence, violating legally established agreements and conditions (Rajagukguk: 13).

Labor arbitration dispute settlement retains its advantages or disadvantages and weaknesses/deficiencies. The advantages or advantages of labor arbitration, namely; Firstly, employers and laborers prefer arbitration rather than through a district court which lacks confidence (Rajagukguk: 2). Secondly, cases handled by arbitrators are not as much as cases handled by judges in the District Court, which are considered ineffective for employers and laborers due to the strenuous process and exorbitant costs. Thirdly, the disputing parties are granted the opportunity to select arbitrators who are presumed capable of adjudicating income disputes. Fourthly, the confidentiality factor of the litigation process and the decision issued are also the main reasons for having arbitration as a choice (Lew: 17). Since arbitration is not obligated to publish a decision.

Weaknesses of labor arbitrage practiced by international labor among others; Firstly, adjoining the will of the disputing parties (laborers and employers) to bring to the arbitration body is a gargantuan task that requires consensus from both parties (Lew, 1993). Secondly, arbitration does not recognize the existence of legal precedents (legal precedents) or attachment to previous arbitration decisions, which may grant the logical possibility of conflicting decisions. Thirdly, arbitration is unable to provide definitive answers for all legal disputes in general and specific income-related labor disputes, and Fourthly, arbitration decisions (Adolf: 2) shall always be dependent on the arbitrator to produce a mutual decision for the parties (Kantaatmadja 1989: 4).

Currently, conflicts that occur between laborers and employers will be resolved by mutual consent as stipulated in Law No. 20 of 2000 concerning Trade Unions / Labor Unions in Article 35, which stated: "Every dispute occurs between trade unions/labor unions, federations and confederations of trade unions/labor unions, federations and confederations of trade unions/labor unions concerned shall be settled by mutual consent ". The chosen arbitrators shall be individuals well known to the parties and free from specific associations (Adolf: 7). 
Labor courts known by the name of the Industrial Relations Dispute Settlement (PPHI) are tasked, namely; to carry out by employers and laborers or trade unions by deliberation to reach consensus, then the completion of deliberations for consensus is regulated by law. The duties and authority of the Industrial Relations court consist of; Firstly, the First Level concerning Rights Disputes. Secondly, the First and Last Level concerning Disputes of Interest, and Thirdly, the First and Last Level concerning Inter Trade Unions Disputes in One Company.

After the enforcement of labor court regulations, namely Industrial Relations Dispute Settlement (PPHI) based on Law No. 2 of 2004 which was ratified and enacted on January 14, 2004, and, came into force January 14, 2005, apparently, the Government prolonged it for another year, so that it only began to be valid January 14, 2006. Types of Industrial Relations Disputes consisted of; Firstly, disputes of interest. Secondly, disputes over rights. Thirdly, disputes over the termination of employment, and Fourthly, disputes between trade unions/labor unions in one company. In the implementation of the labor system or better known as Industrial Relations Dispute Settlement (PPHI) based on Law No. 2 of 2004 which came into force on January 14, 2005, then postponed a year later, The government can no longer avoid the enactment of such law.

Various meetings between the President of the Republic of Indonesia, Dr. Susilo Bambang Yudhoyono (SBY) with foreign businessmen stated that the core problems faced by Indonesia started from; Firstly, there is no existing Investment Law. Secondly, the Tax Law is not conducive, and Thirdly, the Labor Law is, and Fourthly, hindering bureaucratic practices. This was mentioned by Prosecutor Susilo Bambang Yudhoyono (SBY) to Thai entrepreneurs in Kuala Lumpur Malaysia (Kompas: 6). If the problem is very clear, then one should seek for the solution without rejection from companies or ever it should just seek for a comprehensive solution which prevents companies from denying the provision of labor income let alone termination of employment (PHK), all depending upon the action of President SBY.

\section{CONCLUSION}

The conclusion from this article are as follows:

Firstly, in the effort to reformulate labor regulations against demands and pressures in income towards prosperity, then the systemic regulation of labor in Indonesia must create legal certainty regarding income and the strictness of the law as enshrined in the constitution (the 1945 Constitution) and to stimulate the 
birth of labor income in general and the provision of livelihoods legislation specifically.

In providing equitable income-based components namely; basic wages, allowances (position allowances, and including consumptive benefits (calculated from work performance and human resources quality based on annual assessment including the number of dependents), and forms of guarantees such as; safety and health insurance, social security, and old age insurance/pensions, also additional forms of bonuses, gratuities, company shares, educational/training/apprenticeship assistance, religious facilities, recreation, and sports facilities.

Secondly, most international external pressure on labor standards in Indonesia came from the WTO, ILO, IMF which was spearheaded by the United States. Internally, ISMNpressed forward with a similar labor rights issue that failure to provide decent income is a violation of human rights in the labor sector. As such, that this country (the Republic of Indonesia) should immediately ratify the entire ILO and WTO conventions into the provisions of its regulations (constitution and legislation) to be recognized as an ILO state member that applies international labor standards.

Another form of pressure is inseparable from the condition of the global economy which certainly affects the condition of industrial businesses, and the equally important matter is that the state's national political conditions may at times create unconducive conditions which in turn stimulates less rational inflation.

Thirdly, the demand for receiving income for labor welfare facilities in Indonesia is still lingered around the provincial minimum wage (UMP), so that laborers through labor organizations may appeal for wage laws. It is understandable if the labor demands arise due to labor regulations (Law No. 13 of 2003 concerning Labor) that have no legal sanctions to employers and laborers should they violate these laws. This occurs due to the legal ruling of the Constitutional Court of the Republic of Indonesia on criminal sanctions that have been proposed by employers.

Lately, the phenomenon striking at labor communities in Indonesia is the government regulation (by the Ministry of Manpower of the Republic of Indonesia) concerning outsourcing employees. This is proof that laborer's bargaining powers in every decision-making remain weak whether at the local or national company level. 
Fourthly, the labor welfare court known as the Industrial Relations Dispute Settlement institution (PPHI based on Law No.13 of 2003 concerning Labor and Law No.2 of 2004 concerning PPHI) is charged with several obligations namely; tasked with being obliged to direct employers and laborers or trade unions by mutual consent, then resolution by mutual consent shall be regulated by law.

The future for wage dispute settlement including labor income dispute in Indonesia shall be labor arbitration. Because employers and laborers prefer labor arbitration rather than through justice. Cases handled by arbitrators are not as many as cases handled by judges in court, so cases are quickly resolved and relatively short, the disputing parties are allowed to choose arbitrators of their choice with the hope of supporting them both in terms of expertise or knowledge on labor issues. This is possible when arbitrators find it difficult to ascertain what is the cause of a dispute and which party must take responsibility. Actually in Indonesia the arbitration legislation (Law No.30 of 1999 concerning Arbitration and Alternative Dispute Resolution. However, the reality is that the regulation is unable to run optimally because since it lacks the necessary strict authority, enabling all labor arbitration stipulations for new opportunities to seek justice via the court system.

The Indonesian labor system is indeed unfortunate. Hopefully, the Indonesian labor system may attain international standards in the future, so that the Indonesian government may avoid the criteria of human rights violators in terms of global labor aspect.

\section{REFERENCES}

Aaron, B. (2007). Comparative Labor Law-Bridging the Past and The Future, 28 Comp. Lab. \& Pol'y J. 377, Comparative Labor Law and Policy Journal, Spring.

Arieff, S. (1986). Himpunan Undang-Undang Hukum Perburuhan di Indonesia. Surabaya: Pustaka Tinta Mas.

Arthurs, H.W. (2007). Compared to What The UCLA Comparative Labor Law Project and the Future of Comparative Labor Law, 28 Comp. Lab. L. \& Pol'y J. 591, Comparative Labor Law and Policy Journal, Spring.

Araki, T. (1994). "Special Section International Collequium on Labor Law: Models of Employee Representational Participation Part II, The Japanese Model of Employee Representational Participation", Comparative Labor Law Journal, (Vol. 15: 143). 
Araki, T. (2007). A Comparative Analysis of Security, Flexibility, and Decentralized Industrial Relations in Japan, Comparative Labor Law and Policy Journal, Spring, 28 Comp. Lab. L. \& Pol'y J. 443, Copyright @ Comparative Labor Law and Policy Journal.

Anggotakan ISMN terdiri dari; YLKI, LBH Jakarata, ELSAM, INFID, LBH, APIK, YLKI dan PMK-HKBP Jakarta.

Anoraga, Pandji. Perusahaan Multinasional dan Penanaman Modal Asing (Pustaka Jaya)

Alston, P. (1993). "Labor Rights Provisions in US Trade Law: "Aggressive Unilateralism", Human Rights Quarterly 15: 1-35 by The Johns Hopkins University Press.

Barbieri, C.T. (1996). "Women Laborers in Transition: The Potential Impact onf The NAFTA Labor Side Agreements on Women Laborers in Argentina and Chile", Comparative Labor Law Journal, Vol. 17: 526.

Biagi, M. (1994). "Recession and The Labour Market: Training for Flexibilty-The Italian case in a Comparative Perspective", Comparative Labor Law Jornal Vol 15.

Bin Md. H. Ahmad, M. (tth). The Textile and Garment Industry, (Pelanduk Publications) Vol. 116.

Brookes, B; Madden, P. (1995). The Globe-Trotting Sport-Shoe, London: Christian Aid, Vol. 18.

Ballon, R.J. (1988). Sistem Penggajian Jepang, penyunting B.N. Marbun, "Manajemen Jepang". Jakarta: Pustaka Binaman Presindo.

Bercusson, B. (1995). "The Conceptualization of European Labour Law", Industrial Law Journal, Vol. 24 No. 1, March @ Industrial Law Society.

Blanchet, Didier. "Does an Agein Labour Force Call for Large Adjustments in Training or Wage Policies", Labor Market in an Agein Europe, Cambridge University Press.

Carrizosa, A.S. (1988). "Standing Committee on Human Rights", Human Rights Organization, Ficial Bulletin, LXXI, Series BNI.

Covington, R.N; Kurt, H.D. (1995). Individual Employee Rights In A Nutshell. (St. Paul, Minn. West Publishing Co).

Covington, R.N; Kurt, H.D (1995). Individual Employee Rights In A Nutshell. Departemen Tenaga Kerja RI. Pembaruan Sistem Upah, Editor Sasono, A dkk (1994). Jakarta: Cides.

Cunningham, W; Mercado, S.L. (1993). "The North American Free Trade Agreement: The Sale of U.S. Inudutry to The Lowest Bidder", Hoefstra Labor Law Journal Vol 10 No 2 Spring.

Covington, R.N; Kurt H.D. (1995). Individual Employee Rights In A Nutshell, 
Cerna, C.M. (1994)."University of Human Rights and Culture Diversity: Implementation of Human Rights in Different Socio-Cultural Contexts", Human Rights Quarterly, Vol.16 740-752 by The Johns Hopkins University Press).

Caire, G. (tth). "Labour Standars and International Trade" International Labour Standars and Economic Interdependence.

Cerna, C.M. (1994). "Universality of Human Rights and Cultural Diversity: Implementation of Human Rights in Different Socio-Cultural Contexts", Human Rights Quarterly, Vol. 16.

Chu, Y.H. (1989). "State Structure and Economic Adjusment of the East Asia Newly Industrializing Countries", International Labor Organization Vol. 43. 4. Autumn by The World Peace Foundation and The Massachusetts Institute of Technology).

Ewing, E.D. (1996). "Democratic Socialism and Labour Law", Industrial Law Journal, Volume 24, June.

Erickson, C.L; Sarosh, K. (1994). "Labor Costs and The Social Dumping Debate in The Eupopean Union", Industrial and Labor Relations Review Vol 48 No (1 October. (Cornel University).

Erickson, C.L; Daniel, J.B.M. (1996). “Labor Standar in International Trade Agreements: The Current Debate", (December), Labor Law Journal, (International Trade Agreements).

Fraser, S.L.W.R. (1991). The Free Press a Division of Macmillan, Inc. New York, Maxwell Macmillan Canada Toronto, Maxwell Macmillan International New York, Oxford-Singapura-Sydney.

Fischel, D.R. (tth) "Labor Markets and Labor Law Compared with Capital Markets and Corporate Law", Labor Law and The Employment Market.

FBA, (2007). Lord Wedderburn. Labour Law 2008: 40 Years on, 36 Indus. L.J. 397, Industrial Law Journal December.

FBA, (1998). "Deregulation and Labour Law in Britain and Western Europe". Hofstra Labor Law Journal, (Vol. No: 1)

Fossum, J.A. (1982). "Labor Relation; Development, Structure, Process", Bargaining Theory and Structure, Business Publications, Inc.

Groding, J. dalam Ian, H, (1993). "The Constitutionalization of Employment Rights: A Comparative View", Berkeley Journal of Employment \& Labor Law, (Vol. 14: 113).

Glick, C.A. (1989). “Labor-Manajemen Cooperative Programs: Do They Foster or Frustrate National Labor Policy", Hofstra Labor Law Journal, (Vol. 7: 1). 
Hansen, J. M. (1990). "Taxation and The Political Economy of the Tarif", International Organization, 44, 4, Autumn, by The World Peace Foundation and The Masschusetts Institute of Technology.

Hayashi, D. (1992). "Preventing Human Rights Abuses in the U.S. Garmen Industry: A Proposed Amandment to the Fair Labor Standards Act", Yale Journal of International Law, Vol. 17: 195.

Hylton, K. N. (1996). "A Theori of Minimun Contract Terms, With Implications for Labor Law." Texas Law Review. Vol. 74: 1741.

Kertanegoro, S. (2002). Pengupahan (Wages). Jakarta: Yayasan Tenaga Kerja Indonesia.

Kompas: 1 Agustus 1998, 3 Maret 1999, 20 September 2000, 25 Januri 2001, 28 Januari 2001, 5 Juli 2001, 17 Nopember 2001, 23 Nopember 2001, 29 April 2006.

Kantaatmadja, K (1989). Beberapa Hal Tentang Arbitrase, Kertas Kerja Pada Penataran Hukum Ekonomi Internasional, (Bandung: Unpad-Utrecht.

Lew, J.D.M. (!993). Determination of Arbitration's Jurisdiction and the Public Policy Limitation onthat Jurisdiction, dalam Adolf, Huala. Arbitrase Komersial Internasional, (Jakarta: Rajawali Press.

Caffrey, M.S.G. (1993). "North American Free Trade and Accomplishments and Challenges", Hofstra Labor Law Journal, Vol. 10: 2 (1993).

Midford, P. (1993). "International Trade and Domestic Politics: Improving on Rogowski's Model of Political Alignments", International Organization 47, 4, Autumn, pp. 535-564@ (1994) by The IO Foundation and Massachusetts Institute of Technology.

Manezas, J. (1981). Law and Absolute Poverty, Valparaiso University Law Review, Vol. 15.

Naskah Persiapan Undang-Undang Dasar 1945, I, (Jakarta: Yayasan Prapantja, 1959.

Nollen, S.D; Dennis, P.Q. (1987). "Free Trade, Strategic Trade and Protectionism in the U.S. Congress", International Organization 48.

Nollen, S.D; Dennis, P.Q. (1987). "Free Trade, Fair Trade, Strategic Trade and Protectionism in The U.S. Congress", Internanational Organization 48. 3 (Summer 1994), pp.491-525 @ (1994) by The IQ Foundation and The Massachusetts Institute of Technology).

Manique, O.J. (1992). Development, Human Rights and Law, Human Rights Quarterly Vol. 14.

Paust, J.J. (1995). “The Human Right to Die with Dignity: A Policy-Oriented Essay". Human Rights Quaterly, 17 by The Johns Hopkins University Press.

Player, M. A. (1992). Federal Law of Employment Discrimination in A Nutshell, St. Paul, Minn. West Publishing Co. 
Rajagukguk, E. (1993). Etika Bisnis dalam Rangka Pembentukan Hukum Bisnis Indonesia, diselenggarakan Senat Mahasiswa FH-Univ. Katolik Parahiyangan di Bandung, tanggal 7-8 Mei.

Rajagukguk, E. (2000). Arbitrase Dalam Putusan Pengadilan. Jakarta: Chandra Pratama.

Romeo, R; Silvana, S. (1995). “The Protection of Employees' Privacy: A Survey of Ilatian Legislation and Case Law." Comparative Labor Law Journal, Vol. 17: 91.

Romeo, R; Silvana, S. (1995). “The Protection of Employees' Privacy: a Survey of Italia Legislation and Case Law", Comparative Labor Law Journal, (Vol. 17: 91).

Republik Indonesia, Undang-Undang No.39 Tahun 1999 tentang Hak Asasi Manusia. Republik Indonesia, Undang-Undang Dasar 1945 dan Amandemen dengan Penjelasan disertai Susunan Kabinet.

Rosen, S.M. (1992). "Protecting Labor Rights in Market Ekonomies", Human Rights Quarterly 14, 371 - 382 @ 1992 by The Johns Hopkins University Press.

Rosen, S.M; Steven, F. A. (1994). "How The Taft Harley Act Hindered Unions", Hofstra LaborLaw Journal, (Vol. 12:1).

Republik Indonesia, Undang-Undang No.12 Tahun 1964 tentang Pemutusan Hubungan Kerja (PHK).

Republik Indonesia, UU No.2 Tahun 2004 tentang Penyelesaian Perselisihan Hubungan Industrial, Lembaran Negara RI, Tahun 2004 No.6.

Republik Indonesia, Undang-Undang Nomor 4 Tahubn 2004 tentang Penyelesaian

Perselisihan Hubungan Industrial, Lembaran Negara Republik Indonesia Tahun 2004 Nomor 6

Republik Indonesia, UU No.30 Tahun 1999 tentang Abitrase dan Alternatif Penyelesaian Sengketa.

Republik Indonesia, UU No.80 Tahun 1957 tentang Persetujuan Konvensi ILO No.100.

Sherman, M; AI, L. (1992). "Positive Discipline and Labor Arbitration", Arbitration Journal, (June).

Peradilan, Varia (1993). Majalah Hukum, Tahun X No.115 April.

Soejono, R. Pedoman Perburuhan, (Jakarta: GCI van Dorp \& Co NV, 1952).

Strauss, G; Leonard, S. (1990). Manajemen Personalia, Segi Manusia dalam Organisasi, (Jakarta: Pustaka Binaman Presindo.

Sulaiman, A. (2002). Perselisihan Buruh: Sektor Usaha Garmen. Jakarta: YPPSDM.

Sulaiman, A. (2003). Tenaga Kerja Indonesia. Jakarta: YPPSDM, 2003.

Sulaiman, A. (2004). Politik Hukum Buruh RI. Jakarta: YPPSDM, 2004. 
Sulaiman, A. (2004). Penelitian Hukum (Kualitatif, Kuantitatif dan Konten), Modul Program Magister Ilmu Hukum.

Sulaiman, A. (2005). Sejarah Hukum Perburuhan di Indonesia, Modul Bahan Materi Hukum Perburuhan Program Pascasarjana Ilmu Hukum, Tahun 2005.

Sulaiman, A. (2006). Peradilan Buruh. Jakarta: Program Magister Ilmu Hukum Pascasarjana Univ. Islam Jakarta.

Sulaiman, A. (2006). Standar Buruh: di Perdagangan Bebas.Jakarta: Program Magister Ilmu Hukum Pascasarjana Universitas Islam Jakarta.

Sulaiman, A. (2006). Standar Buruh di Jepang, Jurnal Reformasi Hukum, Vol. 2. Sulaiman, A (2008). Upah di Indonesia. Jakarta: Universitas Trisakti, 2008.

Sulaiman, A (2016). Fundamen Hukum Perburuhan Terhadap Pemberian Penghasilan dalam Era Globalisasi di Indonesia, Hukum Ekonomi Indonesia (Kumpulan Karangan), Editor; Nurul Elmiyah-Rosa Agustina. Jakarta: FHUI, Mei.

Sulaiman, A. (2019) dan Andi, W. Hukum Ketenagakerjaan/Perburuhan. Jakarta: YPPSDM Jakarta, 2019.

Stutzman, A.K. (1993). “Our Eroding Industrial Base: U.S. Labor Laws Compared with Labor Laws of Less Developed Nations in Light of the Global Economy", 12 Dick J. Int'l Law, Fall.

Summers, C. (1992). “Lord Edderburn's New Labour Law: An American Perspective", Indutrial Law Journal, Vol. 12 No. 3 September Industrial Law Society).

Shamad, Y. (1992). Pengupahan Pedoman bagi Pengelola Sumber Daya Manusia di Perusahaan. Jakarta: Bina Sumber Daya Manusia.

Spracker, S.M; Gregory, J.M. (1993). "Labor Issue Under the NAFTA: Options in the Wake of the Agreement", The International Lawyer, Vol. 23. No. 3, Fall

Surin, E.C. (1992). "Government Influence on Labor Unions in A Newly Industrized Economy: A Look at the Singapure Labor System", Comperative Labor Law Journal, (Vol. 18: 102).

Subekti, R; Tjitrosudibio, R. (1980). Kitab Undang-Undang Hukum Perdata, Terjemahan Burgerlik Wetboek. Jakarta: Paradnya Paramita.

Suziani. (tth). Kasus Nike di Indonesia, Meneropong Kondisi Kerja Buruh Perusahaan Sepatu Olahraga, (Jakarta: Praninta Jaya Mandiri)

Vranken, M. (1994). "Demise of the Australian Model Labor Law in the 1990s", Comparative Labor Law Journal, (Vol. 16: 1).

Wet, E.d. (1995). “Labor Standars in The Globalized Economy: The Inclusion of a Social Clause in The General Agreement On Tarif and Trade/World Trade Organization." Human Rights Quarterly. 17 443-462 by The Johns Hopkins University Press. 
Wedderburn, L. (2007). Labour Law: 40 Years on, Industrial Law Journal. December, 36 Indus. J.L. 397, Copyright by Law Society.

Zifchak, W.C. (1983). "Collective Bargaining in The Reagan Era: A Management Perspective", Hofstra Labor Law Forum, Volume I. No. I, Winter. 